\title{
SYMPOSIUM ON TRANSNATIONAL FUTURES OF INTERNATIONAL LABOR LAW
}

\section{REIMAGINING TRADE AGREEMENTS FOR WORKERS: LESSONS FROM THE USMCA}

\author{
Alvaro Santos*
}

A backlash against the post-Cold War order of liberal globalization has taken hold in the rich North Atlantic countries. Concerns about wages, working conditions, and economic opportunity are central to the critique of international trade agreements of the last three decades. While labor rights have progressively been included in trade agreements, they have done little to reshape workers' well-being and workplace conditions. The new United States-Mexico-Canada Agreement (USMCA) ${ }^{1}$ may signal a pivot to a new model requiring reforms of domestic labor law and other issues important to workers. However, there is much more to be done to rebalance the power between capital and labor in trade agreements. In addition, for the United States and other rich countries, reform at home may be equally important.

\section{Goodbye to the Gold Standard of Liberal Globalization?}

The centennial anniversary of the International Labour Organization (ILO) provides an opportunity to reflect on the status of workers in the global economic order. For the last twenty-five years, liberal globalization's default proposal to address workers' concerns was to include a labor chapter with minimum standards in trade agreements. Starting with the North American Free Trade Agreement (NAFTA), labor provisions have evolved along three main axes. First, there has been a move from nationally defined labor rights to internationally defined ILO core labor standards on freedom of association and collective bargaining, forced labor, child labor, and nondiscrimination. Second, labor rights have been included in a chapter of the trade agreement rather than in a side agreement, and are subject to the same dispute settlement system as other trade obligations. Third, violations of labor obligations can formally give rise to trade sanctions, such as tariffs imposed by the affected party or compensation by the party in breach. ${ }^{2}$

The apex of this progressive evolution was the Trans-Pacific Partnership (TPP). During the negotiations, the Obama administration lauded "the strongest labor provisions of any trade agreement in history,"3 and U.S. Secretary of State Hillary Clinton characterized the TPP as the "gold standard" of trade agreements in part

* Professor of Law, Georgetown University Law Center. Deputy Chief Negotiator of the USMCA on behalf of the elected government of Mexico, July-Dec. 2018.

${ }^{1}$ Office of the U.S. Trade Rep., Exec. Office of the President, Agreement between the United States of America, the United Mexican States, and Canada 05/30/19 Text (2018) [hereinafter USMCA].

2 Álvaro Santos, The Lessons of TPP and the Future of Labor Chapters in Trade Agreements, in Megaregulation Contested: Global Economic Ordering After TPP 140, 140-74 (Benedict Kingsbury et al. eds., 2019).

${ }^{3}$ Office of the U.S. Trade Rep., Exec. Office of the President, The Trans Pacific Partnership: Protecting Workers.

(C) Álvaro Santos 2019. This is an Open Access article, distributed under the terms of the Creative Commons Attribution licence (http://creativecommons.org/licenses/by/4.0/), which permits unrestricted re-use, distribution, and reproduction in any medium, 
due to its "strong protections for workers."4 TPP included new obligations such as to "adopt and maintain" laws and practices governing "acceptable conditions of work with respect to minimum wages, hours of work, and occupational safety and health," and not to derogate from existing labor laws. ${ }^{5}$

In many ways, this was the furthest a trade agreement had gone on workers' rights and, by that measure, it was the gold standard. However, unions and workers' organizations in the United States criticized the TPP labor chapter for its vague language, weak protections, huge procedural hurdles, and ineffective remedies. ${ }^{6}$ In their view, the innovations were limited and aspirational. One could conclude that if this is the best liberal globalization could do, then the TPP model should be abandoned as the gold standard of trade agreements. ${ }^{7}$

The USMCA in many ways resembles NAFTA and the TPP. Yet important provisions on labor, investment, and rules of origin in the USMCA indicate a break with the gold standard and suggest a rebalancing in a somewhat more positive direction.

\section{Labor Reform in Mexico}

The USMCA contains a labor chapter with some provisions that improve on the TPP. For instance, it includes provisions on violence against workers, migrant workers, and sex-based workplace discrimination. ${ }^{8}$ The Agreement also affirms that the right to strike is a central part of the right to freedom of association. ${ }^{9}$ In addition, it reduces the threshold to claim that a party's failure to enforce its labor law commitments is "in a manner affecting trade" and thus be deemed a violation of the Agreement. ${ }^{10}$ The USMCA eliminates the requirement, established in the U.S.-Guatemala panel under the Dominican Republic-Central America-United States Free Trade Agreement, ${ }^{11}$ that a party's failure to enforce its labor laws "confers some competitive advantage on an employer ... engaged in trade between the parties." ${ }^{2}$ The USCMA requires a trade relation but not the conferral of a competitive advantage.

The chapter's most significant feature, however, is Mexico's commitment to overhauling its domestic labor laws and institutions. While negotiating the TPP, Mexico amended its Constitution to introduce labor reform. However, when the United States withdrew from the TPP, that reform stalled. ${ }^{13}$ The commitment in the USMCA is consistent with the new government's progressive labor reform agenda but now the USMCA-if the U.S. Congress approves it-locks in this domestic labor reform, making it less susceptible to being rolled back by future administrations.

${ }^{4}$ Michael A. Memoli, Hillary Clinton Once Called the TPP the "Gold Standard.” Here's Why, and What She Says About the Trade Deal Now, L.A. Times (Sept. 26, 2011).

${ }^{5}$ USMCA, supra note 1, arts. 19.3.2 and 19.4.

${ }^{6}$ See, e.g., AFL-CiO, A Gold Standard for Workers? The State of Labor Rights in Trans-Pacific Partnership Countries (2016).

${ }^{7}$ Santos, supra note 2.

${ }^{8}$ USMCA, supra note 1, arts. 23.7, 23.8, and 23.9.

9 Id. art. 23.3.1(a) n.5.

${ }^{10}$ Id. art. 23.3 n. 4 .

${ }^{11}$ Dominican Republic-Central America-United States Free Trade Agreement art. 16.2:1(a), 43 ILM 514 [CAFTA-DR] (adopted Aug. 5, 2004).

12 Arbitral Panel, In the Matter of Guatemala-Issues Relating to the Obligations Under Article 16.2.1(a) of the CAFTA-DR, Final Report, para. 190 (June 14, 2017).

${ }^{13}$ Santos, supra note 2, at 158. 
The domestic labor reform, which became law on May 2, 2019, consists of three main changes. ${ }^{14}$ First, the law brings labor disputes into the jurisdiction of Mexican courts and the judiciary, eliminating the arbitration and conciliation boards that were part of the executive branch and that generally reached decisions favorable to employers and traditional, progovernment and corporatist unions. Second, it creates an autonomous center for labor conciliation and registration, which will register unions and collective agreements and certify union leadership, taking this authority away from the Ministry of Labor, which often intervened in favor of progovernment unions. Third, the law provides that the center will verify that personal, free, direct, and secret elections determine union leadership and majority support of collective agreements. ${ }^{15}$

In addition, in November 2018 the Mexican Senate ratified The Right to Organise and Collective Bargaining Convention, 1949 (No. 98), ${ }^{16}$ which enshrines the right to organize and collective bargaining. These changes will benefit Mexican workers as well as the Mexican economy, which has relied on cheap labor via repressed wages as part of its economic development strategy for the last three decades without much success. ${ }^{17}$ If implemented effectively, the reform will gradually result in higher wages that would in turn help to increase domestic demand. This also means that employers will have to find other forms of competitive advantage beyond cheap labor, via innovation in products, production processes, or business strategy. Workers could finally form genuine unions, elect their leadership, and bargain collectively with employers.

\section{The Elusive Promise of Benefits for U.S. Workers}

Much of the current debate around the ongoing USMCA ratification process in the United States implies that the future of American workers depends on compliance with labor reform in Mexico. ${ }^{18}$ But the focus on Mexico may serve as a smoke screen that obscures the flaws of U.S. labor laws and institutions. The North American Agreement on Labor Cooperation (NAALC) was rightly criticized for its weak enforcement provisions given that it provided a separate dispute settlement system and allowed remedies only for a limited number of rights. Moreover, none of the complaints advanced beyond the consultations phase and no panel was ever established. The NAALC nevertheless raised awareness of labor violations in all three NAFTA parties. It also encouraged workers to mobilize transnationally, forge common ground, and build alliances. ${ }^{19}$

Complaints brought against the United States under the NAALC included violations of: the right of freedom of association and collective bargaining in the form of employer intimidation and unfair dismissal; minimum employment standards concerning wages, including unpaid minimum wages or overtime; and applicable working-condition laws, including health and safety. ${ }^{20}$ These violations are not new. Worker organizations have brought similar

\footnotetext{
${ }^{14}$ Diario Oficial de la Federación, Decree Announcing Reform, Additions to and Repeal of Several Provisions of the Federal Labor Law (May 1, 2019) (Spanish).

${ }^{15}$ For many years, parties in Mexico unsuccessfully proposed versions of these labor reforms. See Álvaro Santos, The Trouble with Identity and Progressive Origins in Defending Labour Law, in Critical Legal Perspectives on Global Governance: Liber Amicorum David M. Trubek 207, 212-16 (Gráinne de Búrca et al. eds., 2014).

${ }^{16}$ Int'l Labour Org., Mexico Ratifies the Right to Organise and Collective Bargaining Convention, 1949 (No. 98) (Nov. 26, 2018).

${ }^{17}$ Christopher Woody, Mexico's Wage Crisis Is So Bad "That It Violates What's Stipulated in the Constitution”, BusInEss InsIDER (Aug. 2, 2015); Lance Compa, Trump, Trade, and Trabajo: Renegotiating NAFTA's Labor Accord in a Franght Political Climate, 26 IND. J. GLOBAL LEGAL STUD. 263, 284-87 (2019).

18 See, e.g., Jenny Leonard \& Nacha Cattan, Congress Aides Plan Mexico Trip to Survey USMCA Labor Progress, Bloomberg (May 29, 2019).

${ }^{19}$ Lance Compa, NAFTA's Labor Side Agreement and International Labor Solidarity, in Place, Space and the New Labour Internationalisms 147-63 (Peter Waterman \& Jane Wills eds., 2001).

${ }^{20}$ See Compa, supra note 17, id. at 275-79; Human Rights Watch, Trading Away Rights: The Unfulfilled Promise of NAFTA's Labor Side Agreement (2001).
} 
complaints before compliance mechanisms under the ILO and the Organisation for Economic Co-Operation and Development. ${ }^{21}$ Scholars have also pointed out the "ossification" of labor law, ${ }^{22}$ regarding it as so dysfunctional that they focus on promising initiatives that bypass the National Labor Relations Act. ${ }^{23}$ Some even view antiunion laws and policies as reasons for the dramatic fall in the private-sector unionization rate, from a 1950s high of 40 percent to 7 percent in 2019. ${ }^{24}$ In the face of employer resistance, workers find it particularly difficult to form unions in the United States. ${ }^{25}$ These obstacles to organizing and bargaining collectively are associated with the rise in income inequality in the United States. Even proliberal globalization economists point to unions as an important market mechanism for more equitable income distribution. ${ }^{26}$

Given vast labor cost differentials, the Mexican labor reforms brought about by the USMCA will probably not affect workers in the United States significantly. To improve wages and working conditions and address job losses to global competition, worker organizations and proworker politicians need a more ambitious domestic agenda in the United States.

\section{Reduction of Investor Rights}

Considerable criticism of trade agreements has focused on investors' rights established therein because they potentially restrict states' regulatory space. For instance, investors may sue states over regulations on public health, environment, or even labor, if they deemed it contrary to their rights. These claims are adjudicated by arbitral panels, subject to no appellate review, which may result in inconsistent or contradictory awards. Arbitrators often serve as counsel in other disputes, raising concerns about potential conflicts of interest. In fact, the most vocal opposition to the TPP in the United States came from scholars, civil society groups, and politicians, centered on the investor-state dispute settlement (ISDS) and the limitations it would impose on the U.S. ability to regulate. ${ }^{27}$

Compared to the TPP, the USMCA significantly reduced the scope of investor rights. Although retaining protections against direct expropriation and discriminatory treatment, the agreement eliminates (except for a few sectors) rights against indirect expropriation (regulatory takings), fair and equitable treatment, and full protection and security. ${ }^{28}$ There are now more stringent requirements for the exhaustion of local remedies before resorting to arbitration. ${ }^{29}$ Finally, ISDS is only applicable between the United States and Mexico, as Canada opted out. ${ }^{30}$ Although the asymmetry of treatment between capital and labor remains concerning their right to sue states and the speed and effectiveness of the remedies, the changes in USMCA mark an important departure from the TPP.

21 James Atleson et al., International Labor Law: Cases and Materials on Workers’ Rights in the Global Economy, ch. 2 (2008).

22 Cynthia Estlund, The Ossification of American Labor Law, 102 Colum. L. Rev. 1527 (2002).

23 Benjamin I. Sachs, Employment Law as Labor Law, 29 Cardozo L. Rev. 2685 (2008).

24 Álvaro Santos, Three Transnational Discourses of Labor Law in Domestic Reform, 32 U. PENn. J. InT'L L. 123, 144 (2010); Irina Ivanova, Union Membership in the U.S. Hit Record Low in 2018, CBS News (Jan. 21, 2019).

${ }^{25}$ Richard B. Freeman, Do Workers Still Want Unions? More Than Ever, Econ. Pol’Y Inst. (Briefing Paper No. 182, 2007).

${ }^{26}$ Lawrence Summers, America Needs Its Unions More Than Ever, FinAnCial Times (Sept. 4, 2019).

${ }^{27}$ Letter from Law and Economics Professors to US Members of Congress (Mar. 11, 2015). But see response in Letter from Professors and Scholars of International Law, Arbitration, and Dispute Settlement to US Members of Congress (Apr. 20, 2015).

${ }^{28}$ USMCA, supra note 1, Annex 14-D.

${ }^{29}$ Id. at ch. 14, art. 14.D.5.

30 The Comprehensive and Progressive Agreement for Trans-Pacific Partnership, which succeeded TPP upon United States' withdrawal, provides ISDS between Mexico and Canada. 


\section{Rules of Origin}

While the TPP decreased the percentage of regional value content for automobiles to enjoy duty-free treatment from 62.5 percent in NAFTA to 45 percent, the USMCA increased it to 75 percent. ${ }^{31}$ It also imposes a new labor value content in autos, requiring that 40 percent of production pay US $\$ 16$ an hour. ${ }^{32}$ Also, certain automobile parts and components must be wholly produced in the region, as must 70 percent of all steel and aluminum content. ${ }^{33}$ These rules seem designed to increase production in North America and divert it away from other supply chains, primarily from Asia.

Critics warn that these rules would increase production costs in North America and raise consumer prices. ${ }^{34}$ Ultimately, the effects may differ in each USMCA party and would depend on how companies adjust. In the case of Mexico, it would also depend on companies' ability to create greater value in the regional supply chain. These rules are another departure from the TPP, with provisions reminiscent of local content requirements to stimulate production in the United States. Although once a common tool of industrial policy, states have long shunned such requirements in trade agreements. The USMCA may indicate the beginning of a shift in vision, where local production, wages, and effects on jobs become more central in negotiating trade agreements.

\section{Retbinking Globalization as if Workers Really Mattered}

Novel provisions in the USMCA provide an opportunity to think about future trade agreements and their impact on workers, and about the role of law in globalization's economic consequences. ${ }^{35}$ The skewed results of liberal globalization should not be surprising. Consider three imbalances in the legal design of gold-standard trade agreements.

First, corporations enjoy a private right of action, can sue states directly, and may obtain monetary damages; workers have no such rights. Trade agreements could allow both investors and workers to sue a state or deny both actors a private right of action, limiting dispute settlements to interstate claims. Moreover, states could explicitly condition the admission of investors' claims or the award of damages on compliance with labor rights. A few agreements have recently headed in this direction. ${ }^{36}$

Second, corporations are well represented in trade negotiations and have successfully advanced their interests. The inclusion of investor rights and the inclusion and steady expansion of intellectual property (IP) rights in trade agreements illustrates this clout. On this latter front, the USMCA actually goes further than the TPP in providing IP protections. Traditionally, worker organizations have not had such access to negotiations.

Third, while trade agreements have enabled high mobility of capital across borders, mobility of labor has remained limited. This asymmetry has weakened the hand of workers when firms threaten to leave or indeed exit. A new model for trade agreements premised on benefiting working people should address this imbalance. While opposition to migration is part of the backlash against globalization, many trade agreements already regulate movement of labor implicitly_and explicitly for high-skilled workers. Explicit regulation for all workers would

${ }^{31}$ USMCA, supra note 1, at ch. 4, art. 4-B.3.

${ }^{32}$ Id. at ch. 4, art. 4-B.7.

${ }^{33} \frac{I d}{\text { d. }}$ arts. 4-B.6 and 4-B.3.7.

${ }^{34}$ Simon Lester and Inu Manak, Evaluating the New NAFTA, Cato Instrtute (Oct. 3, 2018).

35 See, e.g., World Trade and Investment Law Reimagined: A Progressive Agenda for an Inclusive Globalization (Álvaro Santos et al. eds., 2019) [hereinafter World Trade].

36 See, e.g., Reciprocal Investment Promotion and Protection Agreement between the Government of the Kingdom of Morocco and the Government of the Federal Republic of Nigeria art. 18, Dec. 3, 2016. 
enable receiving countries to formalize migration flows, define temporal scope, screen for security concerns, and obtain trade concessions from sending countries. In addition, sending countries would need to curb undocumented migration. If rich countries recognized their ample use of foreign labor and the economic contributions of foreign workers, migration flows could become more orderly, shrinking trafficking networks and their tragic toll on human life. Wishing migration away will not make it disappear. States could engage in sector-by sector reciprocal negotiations as in the General Agreement on Tariffs and Trade or use a modular system as in the General Agreement for Trade in Services, which already contemplates cross-border movement of natural persons. The goal would be to move gradually and on specific sectors, to experiment and expand where there is demand for foreign workers. ${ }^{37}$

\section{Conclusion}

Liberal globalization is under attack for the inequitable consequences it has generated, where the losers must fend for themselves. The economic grievances of the emerging nationalist movements, even if expressed in xenophobic or racist rhetoric, are powerful. The challenge for trade agreements is to address, not dismiss, those grievances and to reshape globalization to improve the lives of ordinary workers. The USMCA includes three important changes that may indicate a new direction in trade agreements for the benefit of workers: (1) it makes domestic labor law reform (though only in Mexico) a central part of the Agreement; (2) it significantly reduces the scope of investor rights, putting limits on ISDS; and (3) it increases regional value content in rules of origin for autos, explicitly trying to stimulate production in North America and prevent job losses in the United States. Much remains to be done, however. A century ago, the ILO founders innovated to improve labor conditions globally. In these testing times, the ILO anniversary may serve as a reminder of the power of institutional imagination to rebalance the asymmetries in trade agreements for the benefit of workers.

${ }^{37}$ Chantal Thomas, Irregular Migration and International Economic Asymmetry, in WORLD TRADE, supra note 35. 